\title{
Identifying teachers' competencies in Finnish vocational education
}

\author{
Annukka Tapani ${ }^{\star 1}$ and Arto O. Salonen ${ }^{2}$ \\ ${ }^{1}$ Tampere University of Applied Sciences, School of Professional Teacher Education, Kuntokatu \\ 3, 33520 Tampere, Finland \\ ${ }^{2}$ University of Eastern Finland, Faculty of Social Sciences and Business Studies, PO Box 1627, \\ 70211 Kuopio, Finland
}

Received: 17.02.2019, Accepted: 23.08.2019, Published: 19.12.2019

\begin{abstract}
Context: In Finland, vocational education has been competence-based and learner-orientated since the beginning of 2018. Teachers' work has changed because there is a need to pay more attention to students and their specific personal needs. Learning processes are planned individually and more learning options are offered in the workplace.
\end{abstract}

Approach: In this article we ask the following: What kind of teachers' competencies can be identified in Finland? The metadata comprises twelve recent pieces of research on teachers' competencies in the field of Vocational Education and Training (VET) in Finland. We apply data-driven content analysis.

Findings: According to our results, the work of vocational teachers included 53 separate skills comprising seven categories of competencies and three main categories of scholarships as follows: Scholarship in teaching and learning relating to pedagogy, guidance and counselling, and interaction, Scholarship in authentic learning and development referring to pedagogical leadership, partnership and innovator competency, and Scholarship in evaluation and monitoring associated with assessment.

Conclusion: The work of vocational teachers in Finland has become fragmented. The fragmented work of a vocational teacher may influence the teacher's identity. The fragmented nature of the work of vocational teachers also raises the need to share expertise in educatio-

*Corresponding author: annukka.tapani@tuni.fi 
nal institutions. Scholarship in teaching and learning, as well as evaluation and monitoring, are related to the more traditional way to be a teacher. The main challenge for teachers in vocational education in Finland is to adopt ways of authentic learning and development.

Keywords: Vocational education, teaching, learning, development, skills, competencies, scholarship, vocational education and training, VET

\section{Vocational education in the Finnish context}

"How much attention should I pay to students' feelings and when can I start to teach?" asked a vocational teacher education student. This question is a typical example of the changes that are occurring in the ways of teaching and learning. There is a need to pay attention to students and their personal needs. The starting point of this research is what it currently means to be a teacher in vocational education in Finland. A role of the vocational teacher is transforming because Finnish vocational education faced its largest reform in 20 years at the beginning of 2018 (Ministry of Education and Culture, 2017).

According to the Law of Vocational Education (2017), in the Finnish education system, following compulsory education of nine years, young people have the possibility of applying for either general or vocational upper secondary education. Both forms of education mean that successful candidates are eligible for higher education (Finlex Data Bank, 2017). More than $40 \%$ of the relevant age group starts vocational upper secondary studies immediately after basic education (Finnish National Agency for Education, 2018a). The law defines the aim of Vocational Education and Training (VET) as training vocational competencies, as well as supporting students in becoming active, stable and civilised citizens and members of society (Finlex Data Bank, 2017).

Competency is related to underlying characteristics that enable an individual to achieve exceptional performance (Dubois \& Rothwell, 2004). In its broadest sense competencies represent knowledge, skills, abilities, attitudes and values that are important for citizens living good life in society. When it comes to professional action in education sector competence describes knowledge, beliefs, motivation, and self-regulation of the teacher (Baumert \& Kunter, 2013). According to Lee Shulman (1986) teaching competencies are about promoting learning so that teacher's professional knowledge about an issue, concept, or phenomena is combined with pedagogical knowledge. Thus, teaching competence is associated with the ability to explain the specific issue, concept, or phenomena in a way that is understandable to students (Shulman, 1986 \& 1987).

The Finnish National Agency for Education (2018b) sets the prerequisites for teachers. Teachers in Finland receive a high level of training. In general education, all teachers are required to hold a master's degree. In vocational education, teachers should hold a master's 
degree or a bachelor's degree and have at least three years' work experience before they can apply to vocational teacher education units (Finnish National Agency for Education, 2018b). Finnish teachers are also highly respected: in the ranking list of trusted organisations, the educational system is ranked fourth after the police, the president and the armed forces (Eva, 2019).

The high level of education required by teachers relates to the respect they receive. If you want a permanent job as a teacher in a vocational school in Finland, you must be qualified (Finlex Data Bank, 1998). It is different in Norway, for example, where there are no national qualification requirements for vocational college teachers and each institution sets its own competence requirements (Cedefop, 2019). Also, the attitude towards qualifications is quite different in the Nordic countries. There is a great variety of unqualified teachers working in vocational education in the Nordic countries: in Denmark, $8 \%$ are unqualified, followed by Finland 20\%, Norway $28 \%$ and Sweden $29 \%$. There are also significant differences in the Nordic countries in how teachers are recruited: in Denmark, if no fully qualified applicants are available for teacher positions, the solution is that qualified teachers will teach more subjects and teachers with no qualifications will not be hired. In the other Nordic countries, teachers who are not qualified are hired more easily. Thus, Denmark attaches more importance to qualifications than the other Nordic countries. This also has a connection to the approach to further education for teachers: more than nine out of ten schools in Denmark and Sweden, eight out of ten schools in Finland and seven out of ten vocational schools in Norway have a special budget for further education for teachers (Ståhle, 2005).

The Finnish vocational teacher education programme (60 credits) includes vocational pedagogical studies, teaching practice, basic studies in education and elective pedagogical studies. Most vocational student teachers hold a master's degree and at least three years' work experience in the field in which they aim to teach. In Finland, the qualification for a vocational teacher can be obtained from universities or universities of applied sciences (Finlex Data Bank, 1998 \& 2014). In Norway, for example, there are various potential ways of becoming a competent vocational teacher: (a) Vocational teacher education, (b) University education or higher education connected with practical training (180 study points), (c) Subject teacher training programme (three year undergraduate programme in teaching of specific school subjects) ("Faglærerutdanning"), and (d) Trade certificate connected with practical training (Utdanning.no, 2019).

The task of Universities of Applied Sciences (UAS) has also changed recently in Finland. Teachers now have three main roles as educationist, researcher and local development expert (Kotila \& Mäki, 2006). Their work has been transformed from teaching alone to teaching interactively in teams and pairs. Teachers no longer just share knowledge; they also take care of the students' individual needs (Tapani \& Salonen, 2019). There is also a collective desire among the five UAS that are licensed to arrange vocational teacher education for teacher 
training to be on the European Qualifications Framework (EQF) level 7 (Saranpää \& Kotila, 2019). Vocational teacher education is no longer in the framework of degrees because in the Finnish educational system, vocational teacher education has no degree status; it is referred to as a qualification (Ministry of Education and Culture, n.d.). According to the vocational teacher education curriculum, becoming a qualified vocational teacher requires 1-2 years of flexible and multiform learning. Most vocational student teachers work as teachers while studying. If student teachers work at a vocational institute, they can use the work as a source of learning (Vocational teacher education, 2019).

Changes in education are associated with changes in society. This is a transformation from regarding teaching as a kind of mass production in the 1970s. Interest in competencebased education and training arose in the 1960s and 1970s in the United States (Biemans et al., 2005). Educational policy in Finland emphasises individual learning pathways but there is also a need for communal skills and co-operation competencies because a lot of learning takes place in the workplace (Ministry of Education and Culture, 2018a). Thus, a lot of networking is also required outside vocational institutions. This challenges teachers to be more multi-skilled and not just experts in their respective fields (Vertanen, 2002; Salonen \& Savander-Ranne, 2015). The shift towards students' individual learning pathways enables individual skills to meet the needs of the workplace in a flexible manner. Opportunities to study have become more diverse. Distance learning has become popular and students have become more self-reliant. A new learning agreement model will facilitate studies in the workplace. Teachers and experts from the field assess the students' performance. It is possible to apply for and start training flexibly according to individual needs. The new model has also impacted funding: it is intended to improve the effectiveness and quality of education and training, and it encourages education providers to more efficiently adopt measures that reduce the discontinuation of studies and recognise skills that have been previously acquired. Education providers are afforded more freedom in terms of how they organise education and training (Ministry of Education and Culture, 2018b).

These days, a new generation of students, learning styles, potential learning environments and the needs of employees are different because of changes in society and throughout the world (Julkunen, 2010). In working life, technological progress is affecting virtually all areas of activity. In the near future there will be new professions, such as AI psychologists and tele-trainers. These could replace previous occupations (Linturi \& Kuusi, 2018). Jobs are not disappearing - they are simply changing their form. In the future, the general skills that will be required will be creative thinking and interaction, the ability to ask the right questions, adaptability and learning how to learn (Asplund \& Kauhanen, 2018). There is also a need for competencies such as self-reflection, problem solving and cooperation (Isacsson, Salonen, \& Guilland, 2016). The teacher's position is definitely significant as far as a sustainable future is concerned. According to John Dewey (1915), "the conception of education as a social process 
and function has no definite meaning until we define the kind of society we have in mind". Identifying the direction of societal development and halting the developmental shifts that narrow the chances of having a good life are more important (Salonen \& Konkka, 2015; Lehtonen, Salonen, Cantell, \& Riuttanen, 2018).

In this research, we attempt to identify teachers' competencies in Finnish vocational education. We focus on VET, and teachers and teacher-educators involved in VET for secondary education, because it is an educational level that has not been extensively studied in Finland. Our specific research question is: What kind of teachers' competencies can be identified in vocational education in Finland?

\section{Materials and methods}

The metadata comprises twelve recent pieces of research on teachers' competencies in the field of VET in Finland. These twelve studies for meta-analysis were chosen from the most recent research, nationally. The studies for meta-analysis were chosen because of the competence and background of the authors in the field of vocational education and vocational teacher education. In other words, we chose these studies because of their quality and their relatively wide understanding of the phenomena of "new ways to be a teacher" (Miles, Huberman, \& Saldaña, 2014). All the studies were conducted from the teachers' perspective. Four studies (Ahonen 2015; Mäki 2012; Kotila \& Mäki 2006; Tapani \& Sinkkonen 2017) relate to the UAS. Eight studies (Heinilä et al., 2018; Heinilä et al., 2017; Kukkonen, 2018; Lintunen, 2017; Malinen \& Salo, 2018; Tapani, 2013; Tapani \& Kukkonen, 2018; Vänskä, 2018) relate to VET. Fourteen of the study authors (Halonen, Heinilä, Kilja, Kotila, Kukkonen, Malinen, Mäki, Niskanen, Potinkara, Raudasoja, Salo, Tapani, Uronen, \& Vänskä) work as teacher-educators and also have a background in vocational teaching.

We applied data-driven content analysis (inductive content analysis) to the research (Elo \& Kyngäs, 2008). First the data were reviewed multiple times. The separate competencies and skills presented in the papers were identified in order to identify the differences and connections between the studies (Silverman, 1993). Similar kinds of words or sentences were collected under different themes. The coding process according to Strauss and Corbin (1990) was applied: in open coding we named and categorised the phenomenon through close examination of the material (Strauss \& Corbin, 1990). The units linked with the teaching competencies in vocational education were the words or sentences from the results and conclusions of the twelve selected research articles. After this, we reduced the themes (Schreier, 2012; Mayring, 2002). We attempted to identify specific features: the context in which the phenomenon is embedded, conditions that give rise to it. Finally, selective coding integrated categories to form a grounded theory - in this case, the structure of scholarships of the vocational teacher 
in Finland (Strauss \& Corbin, 1990). Even if a data-driven approach was applied, we were aware that existing theories and pre-knowledge exist in the research process.

\section{Results}

Our results are based on the analysis of twelve pieces of research on teachers' competencies in the field of vocational education in Finland. The first research we analysed was by Henna Heinilä, Ilkka Uronen and Heli Potinkara (2017), who studied teachers working in five vocational schools. They stated that, more than ever before, teachers must work as networkers and individual study counsellors. A teacher's work is more related to nurturing and there is a need for multisectoral and multi-professional networking. These changes make it difficult for teachers to develop their work logically. Teachers act more like a counsellor or coach, which means that students must increasingly be responsible for their studies (Heinilä, Uronen \& Potinkara, 2017).

According to Lea Lintunen's (2017) study, there is a need to focus on a teacher's mental development, skills for developing learning environments, teamwork, cooperation - especially with working life - digital teaching skills, knowing qualifications and curricula, recognising individual students' learning opportunities, understanding economics, and also having the ability to support student development (Lintunen, 2017).

Harri Kukkonen (2018) interviewed five vocational teachers. He found three dimensions of vocational teacher identity positions as follows: substance expertise, didactic expertise, and pedagogical expertise. The identity position of vocational teachers included various competencies. A teacher is an educator, expert of the field, integrator, producer of employees, critical evaluator, regenerator of the organisation, developer of working life, creator of a positive atmosphere, and person who understands students' life worlds (Kukkonen, 2018).

Anita Malinen and Petri Salo (2018) showed that teachers' work is more complex than before. Guidance and assessment competencies are required in a work context, meaning that networking, interaction and cooperation are becoming core competencies. It demands deeper participation in social practices: the teacher guides the students and there is a need to recognise and identify their competencies. This also applies to the teachers themselves: they need to recognise their own tacit knowledge and share and discuss it with colleagues. There is also a need for teachers to self-reflect (Malinen \& Salo, 2018).

According to Pia Ahonen (2015), a master's degree teacher builds bridges between working life, students and education. Teachers are increasingly becoming reformers of working cultures in their own institutions, in working life and among other stakeholders (Ahonen, 2015). Pedagogical leadership is an important skill for future teachers: teachers must address their own well-being and be capable of multitasking and handling fragmented roles, for example (Heinilä et al., 2018). 
Kimmo Mäki and Hannu Kotila (2006) also see teachers in UAS as bridge builders: they connect working life and education. Their study revealed a need for teachers to rethink where, how and when students can learn. Thinking that students can also learn outside the classroom and can learn without being taught in a traditional way represents a remarkable change (Mäki \& Kotila, 2006). Research on vocational teacher education (Tapani, 2013) and on master's degrees in universities of applied sciences (Tapani \& Sinkkonen, 2017) shows that the new way of teaching has many similarities to entrepreneurial teaching: both should aim to see possibilities, not obstacles. It is also good to have the courage to do things differently and use creative methods and support an experimental culture. Teaching is moving towards collectivism: the traditional "one-teacher-in-the-classroom" no longer exists. Team teaching, pair teaching, networking and cooperation are the key issues (Tapani, 2013; Tapani \& Sinkkonen, 2017).

In Annukka Tapani's research (2013), the student teachers $(n=15)$ and teacher-educators $(n=11)$ evaluated what the competencies of vocational teachers would be in 2020 . The roles suggested were teacher-counsellor, innovative entrepreneur, networker and consultant. The teacher-counsellor is a skilled educationist who uses technology and new teaching methods and enables individual pathways. The innovative entrepreneurial teacher is capable of finding, applying, trying and developing him/herself but is also able to co-operate with entrepreneurs, public sector and third sector. Networkers have the skills to cooperate, create and maintain contacts and develop education together with stakeholders. Consultants have a communicative and deliberative way of working; they can share their knowledge and utilise other people's skills and knowledge (Tapani, 2013).

Henna Heinilä et al. (2018) reported a study in which a total of 1,476 teachers and teaching staff members of vocational schools participated. This was a national research project that took place in Finland in 2017. The research highlighted six themes as being competencies of future vocational teachers: the competence to guide students in their Personal Competence Development plans (PCDPs), partnership and networking competencies, guidance, new ways of teaching and learning, self-management and quality awareness (Heinilä et al., 2018).

Kirsti Vänskä (2018) emphasised guidance competencies that permit students to become more "visible": a teacher should have empathy skills, a positive attitude, dialogue skills, the will to ask questions and listen to responses, as well as skills relating to reflection and resilience. Acting in this way permits learners to experience motivation and meaningfulness. According to Vänskä it is important to build a shared counselling space and support the learners' initiatives, self-efficacy, participation and sense of belonging (Vänskä, 2018).

Annukka Tapani and Harri Kukkonen (2018) compared how well the competencies and contents of the curriculum of Tampere University of Applied Sciences (TAMK) Vocational teacher education met the future needs of vocational teachers (Tapani \& Kukkonen, 2018). The competencies in the curriculum comprise assessment competency, cultural competency, 
facilitation competency, partnership competency and well-being competency (TAMK, 2018). This study revealed that the competencies of the TAMK curriculum cover the primary needs of future teachers. However, more attention should be paid to mental development, group dynamics and creating a positive atmosphere, documentation skills, i.e. how to document the students' progress in diverse learning environments, interaction skills, marketing skills, and an experimental culture, including an entrepreneurial way of working and managing one's work (Tapani \& Kukkonen, 2018). In Table 1 we summarise the findings as a synthesis of the teaching competencies in vocational education in Finland. According to our results, 53 different skills were recognised on multiple levels: some of the skills were quite specific, such as "documentation skills"; some were broader, such as "understanding life worlds". We identified seven main categories of competency. These competencies formed three main categories of scholarships.

Table 1: Summary of the findings of the teaching competencies in vocational education in Finland

\begin{tabular}{|c|c|c|}
\hline Sub-category (skills) & $\begin{array}{l}\text { Generic category } \\
\text { (competencies) }\end{array}$ & $\begin{array}{l}\text { Main category } \\
\text { (scholarship) }\end{array}$ \\
\hline $\begin{array}{l}\text { - teaching skills } \\
\text { - regeneration of pedagogical skills, using innovative teaching } \\
\text { methods and trying new ways of teaching } \\
\text { - being familiar with the curricula and qualifications } \\
\text { - transforming skills: teacher-counsellor, teacher-guide } \\
\text { - understanding the diverse life worlds of students } \\
\text { - educational skills } \\
\text { - recognising individual learning opportunities } \\
\text { - facilitating skills } \\
\text { - expert in a trade or vocation (subject matter knowledge) } \\
\text { - innovative, entrepreneurial, creative teacher }\end{array}$ & $\begin{array}{l}\text { Pedagogical } \\
\text { competency }\end{array}$ & \multirow[t]{3}{*}{$\begin{array}{l}\text { Scholarship in } \\
\text { teaching and } \\
\text { learning }\end{array}$} \\
\hline $\begin{array}{l}\text { - nurturing skills } \\
\text { - supporting individual learning pathways (study personalisa- } \\
\text { tion) } \\
\text { - supporting learners' initiatives and self-efficacy } \\
\text { - identification and recognition of competencies } \\
\text { - study counsellor, teacher guide } \\
\text { - knowledge about the educational system as a whole } \\
\text { - positive attitude towards learning opportunities } \\
\text { - empathy skills } \\
\text { - dialogue skills } \\
\text { - coaching skills }\end{array}$ & $\begin{array}{l}\text { Guidance and coun- } \\
\text { selling } \\
\text { competency }\end{array}$ & \\
\hline $\begin{array}{l}\text { - creating and ensuring a positive learning atmosphere } \\
\text { - skills to support the students' self-esteem } \\
\text { - digital teaching skills } \\
\text { - creating a sense of belonging }\end{array}$ & $\begin{array}{l}\text { Interaction } \\
\text { competency }\end{array}$ & \\
\hline
\end{tabular}




\begin{tabular}{|c|c|c|}
\hline $\begin{array}{l}\text { - management } \\
\text { - taking care of student well-being } \\
\text { - skills to adopt new roles } \\
\text { - self-reflection } \\
\text { - ability to multitask } \\
\text { - ability to cope with fragmented work }\end{array}$ & $\begin{array}{l}\text { Competency in } \\
\text { pedagogical } \\
\text { leadership }\end{array}$ & $\begin{array}{l}\text { Scholarship in au- } \\
\text { thentic learning and } \\
\text { development }\end{array}$ \\
\hline $\begin{array}{l}\text { - cooperation skills (will and attitude to ensure cooperation) } \\
\text { - multi-professional networking } \\
\text { - multi-sectoral networking } \\
\text { - enabling authentic learning } \\
\text { - helping stakeholders with guidance and documentation } \\
\text { - organisational regeneration } \\
\text { - greater participation in social practices } \\
\text { - taking care of partnerships } \\
\text { - shared expertise (e.g. team teaching, pair teaching) } \\
\text { - bridge building skills } \\
\text { - consulting skills }\end{array}$ & $\begin{array}{l}\text { Partnership } \\
\text { competency }\end{array}$ & \\
\hline $\begin{array}{l}\text { - marketing skills } \\
\text { - economical understanding } \\
\text { - knowledge about competent employees } \\
\text { - understanding of quality } \\
\text { - reflection and resilience skills } \\
\text { - attitudinal skills for mental development } \\
\text { - developing learning environments } \\
\text { - developing working life } \\
\text { - transforming society }\end{array}$ & $\begin{array}{l}\text { Innovator } \\
\text { competency }\end{array}$ & \\
\hline $\begin{array}{l}\text { - documenting the students' learning process } \\
\text { - sharing assessment knowledge in authentic learning envi- } \\
\text { ronments } \\
\text { - willingness to help working life partners with assessment }\end{array}$ & $\begin{array}{l}\text { Assessment compe- } \\
\text { tency }\end{array}$ & $\begin{array}{l}\text { Scholarship in evalua- } \\
\text { tion and monitoring }\end{array}$ \\
\hline
\end{tabular}

Scholarship in teaching and learning is based on three generic categories. The first generic category of competencies addresses pedagogy: they show a tension of being a traditional teacher in the new vocational education. The skills range from substance orientation to entrepreneurial and experimental ways of being a teacher. Guidance and counselling refer to skills ranging from empathy, support and dialogue to the identification of prior skills and understanding the educational system as a whole. The third generic category is about interaction: its content concerns how to create a positive atmosphere for learning, how to support the students' self-esteem and how to use digital tools for teaching.

Scholarship in authentic learning and development is about pedagogical leadership, partnership competency and innovator competency. Pedagogical leadership is associated with management, self-reflection and skills to adopt new roles. Partnership competency comprises skills that enable authentic learning, multi-professional and multi-sectoral networking, 
participation, teamwork and being a peer consultant. Innovator competency is about marketing, and economic understanding, as well as reflection and the skills to develop and see "outside the box".

Scholarship in evaluation and monitoring relates to assessment competency. Assessment competency is about being an expert in assessment as well as showing a willingness to help stakeholders with assessment.

\section{$4 \quad$ Discussion and concluding remarks}

In this research, we were interested in learning about the kind of teaching skills, competencies and scholarships that could be identified in vocational education in Finland. This research has some limitations. Firstly, our data were derived from only 12 previous research articles. Secondly, we analysed the metadata using data-driven content analysis. Thus, some information may have been lost that would have been essential in identifying the skills, competencies and scholarships of vocational teachers. To increase the reliability of the study, we have attempted to formulate this report with an accuracy that enables replication of this study. We also formulated our research question as clearly as possible and we believe that our findings show meaningful parallelism across data sources. In addition, we specified analytic constructs in sub-categories, generic categories and main categories (Miles, Huberman \& Saldaña, 2014).

According to data regarding twelve studies on vocational education, we identified three main categories of scholarship with seven generic categories of competencies and 53 separate skills within them. The main categories relating to vocational teachers' scholarships comprised Scholarship in teaching and learning, Scholarship in authentic learning and development, and Scholarship in evaluation and monitoring. These scholarships included seven competencies:

- Pedagogical competency

- Guidance and counselling competency

- Interaction competency

- Competency of pedagogical leadership

- Partnership competency

- Innovator competency

- Assessment competency

Scholarship in authentic learning and development comprises skills that enable authentic learning in various learning environments. This is related to the reform of vocational education (Ministry of Education and Culture, 2018a) that emphasises productivity and a quick entry 
into working life. Authentic work-based learning is an effective way for students to have specific occupational skills and employability. Managing of the authentic and effective learning environments is not easy task to do for the traditional teachers who are used to operate in a classroom. It is not possible without multi-professional and multi-sectoral networking. On the other hand, effective learning outcomes can be achieved in many different ways: learning independently, being taught or learning by doing.

Scholarship in teaching and learning is related to the more traditional way to be a teacher. An effective way of teaching may combine a personalised, tailored way of learning with a strict, structured and general way of learning. It may be student-centred, teacher-centred or curriculum-centred (Biesta, 2015; Dewey, 1915). Scholarship in evaluation and monitoring overlaps other identified scholarships. It is about being an expert in assessment as well as showing a willingness to help stakeholders with assessment.

In order to have positive and effective learning outcomes it is necessary for teachers to see the learning options from the students' perspectives. Students in vocational education expect authentic learning opportunities, cooperation and guidance for their needs and aims (Tapani \& Salonen, 2019). This is demanding because students have various backgrounds. For example, the vocational education and training of young people and adults is consolidated in Finland. Students under 20 years of age comprise 31\% of all students, students from 20-39 years of age comprise the main population (47\%) and there are also students who are over 40 years of age (22\%) (Vipunen, n.d.).

A tension between individual and societal needs can be seen in the new vocational education and training plan (Ministry of Education and Culture, 2018a): as a starting point for creating a Personal Competence Development Plan (PCDP), there are ideas relating to both the needs of human growth and competence needs of entrepreneurs, public sector and third sector. According to Cedefop (2019), on a European scale, vocationally-orientated education and training at higher levels (levels 5 to 8 of the European qualifications framework) take many forms. In most cases, they have not been clearly defined. Some aspects are of great importance to further development, for example, considering the needs of labour market demands and wider societal values and the balance between academic and vocational principles. There is also a need to consider the balance between academic and vocational qualifications (Cedefop, 2019).

Our conclusion is that in Finland, the competencies of vocational teachers are fragmented. The fragmented competencies of vocational teachers have also been identified in other European countries (Grollmann, 2008). The fragmented competencies of vocational teachers raise concerns about the fragmented day-to-day work of vocational teachers. The fragmented nature of the work of a vocational teacher may influence the teacher's identity: what does it mean to be a teacher today and in the future? There is a trend to avoid using teacher but instead use coach, mentor or facilitator (Maunu, 2018). The word teacher is strongly redolent 
of traditional methods when teaching was performed by one specialist inside the classroom. Teaching was akin to factory work and teachers treated people like the masses: the teacher took charge and used the questions and answers method. Learning was a sedentary task for the students (Ojanen, 2012).

The fragmented work of vocational teachers raises a need to share expertise in their dayto-day work. This is essential because it is impossible for one person to possess all the identified skills, competencies and scholarships. However, by working in pairs or in teams it is possible to fulfil all the needs of the vocational teacher. Shared expertise enables everyone to concentrate on their own strengths. It is a way of working that will promote well-being, communality and social capital at work. It also could be a way of achieving peer learning and peer support and teacher's professional development (e.g. Salonen \& Savander-Ranne, 2015). Moreover, shared expertise enables the experience of being a meaningful part of society (Salonen \& Tapani, 2019).

Even though we found various skills, competency categories and scholarships for vocational teachers, most students are still searching for simple basic things: they expect their teachers to be role models of the profession, guides and experts in learning (Tapani \& Salonen, 2019). Students just want to find their place in society, study, graduate, find a job and start a family (Maunu, 2018). This relates to the core of VET: the aim is to train vocational skills and competencies as well as support students in becoming active, stable and civilised citizens and members of society. Cedefop (2019) suggests that in adding vocational drift there should be greater emphasis on employing teachers who have comprehensive work experience, possibly in addition to their academic degree (Cedefop, 2019). New content of vocational teacher's work could also be used to tempt new teachers. In Finland, the number of applicants has varied quite a lot (Luukkainen, 2019).

Fragmented vocational education also challenges the way in which to conduct vocational teacher education. The identified skills, competencies and scholarships (Table 1) could serve as a checklist for the teacher-educators and trainers. The ideal situation would be that teacher-educators could also work on their strengths and co-operate with others in order to achieve the best learning results for students. That is why connections with stakeholders, peer learning and peer teaching could be used more. According to this, teacher education should be more network-based: teacher-educators together with student teachers can find potential learning environments for different needs (Tapani \& Kukkonen, 2018). One potential way forward is also mentoring. In order to overcome the challenge of the new identity of the vocational teacher, in Finnish vocational teacher education, student teachers are asked to discuss their theory of practice with their mentors (Teacher Education, 2018). This means that student teachers learn to identify themselves as a teacher (Ahlman, 1967). They describe how they feel about learning, knowledge and being human. This may also help them understand what kind of values they promote. One possible way is for teacher education to also move 
towards becoming competence-based: the student teachers study the themes that are important to their development and with which they are not already familiar (Tapani \& Kukkonen, 2018). However, there is a concern that education about competences is too narrow. In order to achieve a meaningful life, not only are the skills required but also an understanding of the world.

In the mid of societal changes, it is important to clarify what the purpose of schooling is and make teachers aware of the impact they make, particularly when fragmentation of the profession is evident. Vocational education contributes to the progress of society (Grollmann, 2008). It supports a social transformation that could improve the conditions for a good life both broadly and profoundly. True opponents this - which must be overcome - are the increasing inequalities between people, public health risks, dirty energy solutions, wasteful industrial processes, atmospheres that negatively impact life, disadvantaged citizens, an uncompetitive economy, as well as all kinds of crooked and unobtrusive factors that stifle the potential of human creation (Salonen, 2014).

As Charles Handy (1989) states, learning is about solving problems by asking, thinking and experiencing until solutions become part of our lives (Handy, 1989). All this has led us to reconsider the concept of the word teacher in vocational education: is it still a relevant word?

Author contributions: This research was carried out interactively: both authors participated in writing the theoretical framework. Annukka Tapani was involved in gathering the data for meta-analysis. The analysis, results and conclusions were written jointly.

Conflicts of interest: The authors declare no conflict of interest.

\section{References}

Ahlman, E. (1967). Arvojen ja välineiden maailma. Eettis-idealistinen maailmantarkastelukoe. [The world of values and tools]. Uusintapainos, alkuperäisteos vuodelta 1920. Porvoo: WSOY.

Ahonen, P. (2015). YAMK-tutkinnon opettajuus sillanrakentajana. [The master's degree teacher as a bridge-builder]. In P. Ahonen (Ed.) (2015) Ylemmän ammattikorkeakoulutuksen opettajuus tutkimuksen, kehittämisen ja uudistamisen sillanrakentajana (pp 20-33). Turun ammattikorkeakoulun raportteja 222. Turku: Turun ammattikorkeakoulu.

Asplund, R., \& Kauhanen, A. (2018). Teknologinen kehitys, ammattirakenteiden muutos ja osaaminen. [Technological development, the change of occupations and competencies.] Ammattikasvatuksen aikakauskirja, 20(1), 91-98.

Baumert, J., \& Kunter, M. (2013). The co-activ model of teachers' professional competence. In M. Kunter, J. Baumert, W. Blum, U. Klusmann, S. Krauss, S., M. Neubrand (Eds.), Cognitive Activation in the Mathematics Classroom and Professional Competence of Teachers. Results from the COACTIV Project (pp. 28-48). London: Springer. 
Biemans, H., Nieuwenhuis, L., Poell, R., Mulder, M., \& Wesselink, R. (2005). Competency-based VET in the Netherlands: backgrounds and pitfalls. Journal for Vocational Education and Training, 56(4), 523-538.

Biesta, G. (2015). What is Education For? On Good Education, Teacher Judgement, and Educational Professionalism. European Journal of Education, 50(1), 75-87.

Cedefop (2019). The changing nature and role of vocational education and training in Europe. Volume 6: vocationally oriented education and training at higher education level. Expansion and diversification in European countries. Luxembourg: Publications Office. Cedefop research paper; No 70. Retrived 26.3.2019, from http://data.europa.eu/doi/10.2801/02004

Dewey, J. (1915). The School and Society. Chicago: University of Chicago Press.

Dubois, D. D., \& Rothwell, W. J. (2004). Competency-based human resource management. Palo Alto, CA: Davies-Black.

Elo, S., \& Kyngäs, H. (2008). The qualitative content analysis process. Journal of Advanced Nursing, 62(1), 107-115.

Eva (2019). Presidentti, EU ja yrittäjät nousussa - suomalaiset luottavat poliisiin [The president, EU and entrepreneurs are rising - Finns trust on the police]. Finnish Business and Policy Forum EVA. Retrieved 11.5.2019, from https://www.eva.fi/blog/2019/04/04/presidentti-eu-ja-yrittajat-nousussasuomalaiset-luottavat- poliisiin/

Finnish National Agency for Education (2018a). Upper secondary education and training. Retrieved 11.12.2018, from http://oph.fi/english/education_system/upper_secondary_education_and_training

Finnish National Agency for Education (2018b). Teacher education. http://oph.fi/english/education_ system/teacher_education.

Finlex Data Bank (2017). The law of vocational education 531/2017. Retrieved 6.3.2018, from https:// www.finlex.fi/fi/laki/alkup/2017/20170531

Finlex Data Bank (2014). The law of universities of applied sciences 14.11.2014/932. Retrieved 26.11.2018, from https://www.finlex.fi/fi/laki/ajantasa/2014/20140932.

Finlex Data Bank (1998). The regulation for teachers' qualifications. Retrieved 26.3.2019, from https:// www.finlex.fi/fi/laki/ajantasa/1998/19980986\#L5. Grollmann, P. (2008). The quality of vocational teachers: Teacher education, institutional roles and professional reality. European Educational Research Journal, 7(4), 535-547. doi:10.2304/eerj.2008.7.4.535

Handy, C. (1989). The age of unreason. London: Business Books Ltd.

Heinilä, H., Holmlund-Norrén, C., Kilja, P., Niskanen, A., Raudasoja, A., Tapani, A., \& Turunen, K. (2018). Rohkeasti uudistumaan! Opetus- ja ohjaushenkilöstön osaamistarpeet - raportti. [A report on competencies concerning teachers and teaching staff]. Parasta osaamista -verkostohanke 3/2018. Retrieved 1.11.2018, from https://blogit.jao.fi/parastaosaamista/2018/03/22/rohkeastiuudistumaan/

Heinilä, H., Uronen, I., \& Potinkara, H. (2017). Osaamisperusteisuuden moninaiset todellisuudet. Ammatillisen koulutuksen muutoksen vaikutukset ammatillisen opettajan työhön. (The changes of vocational education and their effects on the vocational teacher's work). Haaga-Helian julkaisut 4/2017. Retrieved 1.11.2018, from http://blogit.jao.fi/parastaosaamista/wp-content/uploads/sites/401/2017/05/TWIST-lopuraportti_verkkovers.pdf

Julkunen, R. (2010). Uuden työ paradoksit. Keskusteluja 2000-luvun työprosesseista. [The paradoxes of the new work]. Tampere: Vastapaino. 
Isacsson, A., Salonen, A., \& Guilland, A. (2016). Transversaalit taidot tulevaisuuden ammattikorkeakoulun mahdollisuutena. [Transversal competences as possibility of university of applied sciences of future]. Ammattikasvatuksen aikakauskirja, 18(4), 61-67.

Kotila, H., \& Mäki, K. (2006). Ammattikorkeakoulun opettajuus. [Teachership in universities of applied sciences]. In H. Kotila (Ed.) Opettajana ammattikorkeakoulussa (pp. 11-26). Helsinki: Edita Prima Oy.

Kukkonen, H. (2018). Osaamisperusteisuus ja opettajan identiteetti. [Teacher identity positions in competency-based education]. In H. Kukkonen and A. Raudasoja (Eds.), Osaaminen esiin - ammatillisen koulutuksen reformi ja osaamisperusteisuus (pp. 24-35). Tampereen ammattikorkeakoulun julkaisuja. Sarja A. Tutkimuksia 23. Retrieved 20.2.2018, from http://www.tamk.fi/-/julkaisuosaaminen-esiin

Lehtonen, A., Salonen, A., Cantell, H., \& , Riuttanen, L. (2018). A pedagogy of interconnectedness for encountering climate change as a wicked sustainability problem. Journal of Cleaner Production 199, 860-867. Available at https://www.sciencedirect.com/science/article/pii/S0959652618321759

Lintunen, L. (2017). Ammatillisen koulutuksen reformin vaikutukset ammatillisen opettajan työhön. [Vocational education and training reform effects to the work of professional]. Opinnäytetyö. Satakunnan ammattikorkeakoulu, liiketalouden koulutusohjelma. Available at http://urn.fi/ URN:NBN:fi:amk-201701061147

Luukkainen, O. (2019). Onko opettajan työn vetovoima katoamassa? [Is the attraction of teacher's work disappearing?]. Retrieved 19.7.2019, from https://www.oaj.fi/ajankohtaista/blogiartikkelit/ ollin-blogi/2019/onko-opettajan-tyon-vetovoima-katoamassa/

Linturi, R., \& Kuusi, O. (2018). Suomen sata uutta mahdollisuutta 2018-2037 [One hundred new possibilities for Finland 2018-2037]. Eduskunnan tulevaisuusvaliokunnan julkaisu 1/2018.

Malinen, A., \& Salo, P. (2018). Ammatillinen opettajuus syvenevänä osallisuutena työelämän käytännöissä. In A. Raudasoja, A. Norontaus, A. Tapani and R. Ylitervo (Eds.) Innokkaasti edelläkävijänä! Kohti opetus- ja ohjaushenkilöstön uudistuvia identiteettipositioita. HAMKin julkaisuja 4/2018.

Maunu, A. (2018). Opettaja, kasvattaja ja jotain muuta. Ammatillisten opettajien ammatti-identiteetti arjen käytäntöjen näkökulmasta. [Teaching, upbringing, and something else. Vocational teachers' professional identity from the perspective of everyday practices]. Ammattikasvatuksen aikakauskirja, 20(4), 70-87.

Mayring, P. (2002). Qualitative content analysis - Research instrument or mode of interpretation? In M. Kiegelmann (Ed.), The role of the researcher in qualitative psychology (pp. 139-148). Tübingen, Germany: Ingeborg Huber.

Miles, M. B., Huberman, A. M., \& Saldaña, J., (2014). Qualitative Data Analysis: A Methods Sourcebook 3rd edition. London: Sage

Ministry of Education and Culture (2018a). Reform of vocational upper secondary education. Retrieved 31.10.2018, from http://minedu.fi/en/reform-of-vocational-upper-secondary-education

Ministry of Education and Culture (2018b). Vocational education and training will be reformed. Retrieved 6.11.2018, from https://minedu.fi/en/article/-/asset_publisher/ammatillinen-koulutusuudistuu

Ministry of Education and Culture (2018c). A strong respect for teachers' qualifications is a reason for good school results in Finland. Retrieved 27.3.2019, from https://minedu.fi/artikkeli/-/asset_publisher/opettajien-vahva-osaaminen-arvostus-ja-itsenaisyys-suomen-koulutusmenestyksen-salaisuus 
Ministry of Education and Culture (2017). Vocational education and training reform approved - the most extensive education reform in decades. Retrieved 19.7.2019, from https://minedu.fi/artikkeli/-/asset_publisher/ammatillisen-koulutuksen-reformi-hyvaksyttiin-suurin-koulutusuudistusvuosikymmeniin?_101_INSTANCE_vnXMrwrx9pG9_languageId=en_US

Ministry of Education and Culture (n.d.). Finnish Education system. Retrieved 19.7.2019, from https:// minedu.fi/en/education-system

Mäki, K. (2012). Teaching professionals and masters of mosaic - Work cultures as the context of action of the teachers in universities of applied sciences. Jyväskylä, Finland: University of Jyväskylä.

Ojanen, S. (2012). Ohjauksesta oivallukseen. Ohjausteorian käsittelyä. [Theory of guidance. From guidance to insight]. Helsinki: Helsinki University Press.

Salonen, A. (2014). Ammattikorkeakoulun oppimiskulttuuri ja opettajan kompetenssit 2020. [Learning culture and teachers' competences in the university of applied sciences]. In P. Keränen, R. Säntti, M. Rantala \& A.-M. Vilkuna (Eds.), Reittejä työelämän murroksessa (pp 66-71). Helsinki: Metropolia Ammattikorkeakoulu. Available at https://wiki.metropolia.fi/download/attachments/60919233/Reitteja_web.pdf?version=1\&modificationDate $=1414744988000$

Salonen, A., \& Konkka, J. (2015). An Ecosocial Approach to Well-Being: A Solution to the Wicked Problems in the Era of Anthropocene. Foro de Educación ,13(19), 19-34.

Salonen, A. Reijonen, M., \& Savander-Ranne, C. (2015). Metropolia Ammattikorkeakoulun organisaatiokulttuuri ja sen muutosmahdollisuudet opettajien kuvaamina. [Changes in the organizational culture at Helsinki Metropolia University of Applied Sciences]. Ammattikasvatuksen aikakauskirja, 17(4), 22-41.

Salonen, A., \& Savander-Ranne, C. (2015). Teachers' shared expertise at a multidisciplinary university of applied sciences. SAGE Open, 5(3), 1-11. Available at https://journals.sagepub.com/doi/ abs/10.1177/2158244015596206

Salonen, A., \& Tapani, A. (in Print) Palkkatyön merkityksellisyys. Ammatillisen koulutuksen opetus- ja ohjaushenkilöstön kokemuksia työstä. [The experiences of meaningfulness in the work of vocational teachers and counsellors]. Työelämän tutkimus 1/2020

Saranpää, M., \& Kotila, H. (2019). Ammatillisten opettajien koulutukset tasolle 7. [Vocational teacher education should be on the EQFM level 7]. Retrieved 26.3.2019, from https://blog.hamk.fi/opeke/ ammopettajien-koulutukset-tasolle-7/

Schreier, M. (2012). Qualitative Content Analysis in Practice. Thousand Oaks: Sage.

Shulman, L. (1986). Those who understand: Knowledge growth in teaching. Educational Researcher, 15(2), 4-14.

Shulman, L. (1987). Knowledge and teaching: Foundations of the new reform. Harvard Educational Review, 57(1), 1-22.

Silverman, D. (1993). Interpreting Qualitative Data. Methods for Analysing Talk, Text and Interaction. London: SAGE Publications.

Strauss, A., \& Corbin, J. (1990). Basics of Qualitative Research: Grounded Theory Procedures and Techniques. London: Sage Publications.

Ståhle, B. (2005). Toisen asteen koulu Pohjoismaissa. Toisen asteen koulujen pohjoismainen vertailu. "Pohjoismainen ISUSS-raportti". [Gymnasieskolan i Norden. En nordisk jämförelse av skolor på gymnasienivå. ”Den nordiska ISUSS-rapporten"]. Retrieved 18.7.2019, from Koulutuksen arviontineuvoston julkaisuja 4. https://karvi.fi/app/uploads/2014/09/KAN_4.pdf 
Tapani, A., \& Salonen, A. (2019). Myönteisten oppimiskokemusten tekijät ja uudistuva opettajuus ammatillisessa koulutuksessa [Positive learning experiences and new ways to be a teacher in vocational education]. Ammattikasvatuksen aikakauskirja, 21(2), 42-57.

Tapani, A., \& Kukkonen, H. (2018). Vocational Teacher Education Facing the Needs of Finnish Future Teachers? In P.-M. Rabensteiner, O. Holz, M. Michielsen (Eds.) Teacher Education, Sustainability and Development. Challenges, Issues, Solutions for Teaching in the 21st Century (pp. 175-185). Erziehungswissenschaft Bd. 86, 2018.

Tapani, A., \& Sinkkonen, M. (2017). Uudenlainen YAMK-opettaja - sanansaattaja vai innovaatioevankelista. [New master's degree teacher: messenger or evangelist of innovations]. Ammattikasvatuksen aikakauskirja, 19(4), 32-47.

Tapani, A. (2013). Ammatillinen opettajankoulutus liikkeessä - kohti tulevaisuuden tuulia vai tämänpäivän toisintoa? [Vocational teacher education on the move - towards new ways or just reflecting the past?]. Available at https://tampub.uta.fi/handle/10024/84945.

TAMK (2018). Vocational teacher education. Retrieved 1.11.2018, from http://www.tamk.fi/web/tamk/ vocational-teacher-education

Teacher education (2018). Curriculum 2018: Vocational Teacher Education. Retrieved 3.4.2019, from http://www.e-julkaisu.fi/tamk/opettajakoulutus/vocational-teacher-education-2018/mobile. html\#pid=1

Utdanning.no (2019). Fag- og yrkesfaglærerutdanning. Retrieved 18.7.2019, from https://utdanning. no/studiebeskrivelse/fag__og_yrkesfaglaererutdanning

Valtioneuvoston asetus ammattikorkeakouluista A 1129/2014. [The statute on universities of applied sciences]. Retrieved 26.3.2019, from http://www.finlex.fi

Vertanen, I. (2002). Ammatillinen opettajuus vuonna 2010. Toisen asteen ammatillisen opettajan työn muutokset vuoteen 2010 mennessä. [Vocational teachership in the year 2010]. Tampere, Finland: University of Tampere.

Vipunen - Opetushallinnon tilastopalvelu. (n.d.). Opiskelijat ja tutkinnot. [The statistics Vipunen of Finnish national agency for education: Students and degrees]. Retrieved 19.7.2019, from https:// vi-punen.fi/fi-fi/ammatillinen/Sivut/Opiskelijat-ja-tut $\neg$ kinnot.aspx

Vocational teacher education (2019). Professional teachers education programme. Retrieved 26.3.2019, from https://www.tuni.fi/en/study-with-us/programmes/professional-teacher-education

Vänskä, K. (2018). Opettaja kohtaamisosaajana ja merkityksellisyyden avaajana. [The teacher's role as an awareness expert and an explainer of the meaningfulness behind a learner's goals.] In A. Raudasoja, A. Norontaus, A. Tapani and R. Ylitervo (Eds.), Innokkaasti edelläkävijänä! Kohti opetus- ja ohjaushenkilöstön uudistuvia identiteettipositioita. HAMKin julkaisuja 4/2018. 


\section{Bibliographical Notes}

Dr Annukka Tapani works as a principal lecturer in Tampere University of Applied Sciences, School of Professional Teacher Education. The title of her doctoral dissertation was "Does the community really count" - identity process and social capital as elements in surviving in insecurity and uncertainty. Her current research interests are in new ways to be a vocational teacher, changes in education and student positions.

Dr Arto O. Salonen works as an associate professor (social pedagogy) in the University of Eastern Finland, Department of Social Sciences. The title of his doctoral dissertation was Sustainable Development and its Promotion in a Welfare Society in a Global Age. His current research is in behavioural change, societal change, sustainable development and transformative social pedagogy. 